\title{
Free Education in Rwanda: Just One Step towards Reducing Gender and Sibling Inequalities
}

\author{
Joseph Nkurunziza, ${ }^{1}$ Annelet Broekhuis, ${ }^{2}$ and Pieter Hooimeijer ${ }^{2}$ \\ ${ }^{1}$ Department of Applied Statistics, Faculty of Economics and Management, National University of Rwanda, \\ P.O. Box 124, Butare, Rwanda \\ ${ }^{2}$ Department of Human Geography and Urban and Regional Planning, Faculty of Geosciences, Utrecht University, \\ Heidelberglaan 2, 3584 CS Utrecht, The Netherlands \\ Correspondence should be addressed to Joseph Nkurunziza, nkurunzizaj@gmail.com \\ Received 1 August 2012; Accepted 4 October 2012 \\ Academic Editor: David Neumann
}

Copyright @ $\odot 2012$ Joseph Nkurunziza et al. This is an open access article distributed under the Creative Commons Attribution License, which permits unrestricted use, distribution, and reproduction in any medium, provided the original work is properly cited.

In 2003, Rwanda introduced free education as part of government policy to improve school enrolment in general and the attendance of deprived children in particular. However, in addition to school fees, other factors hamper school careers of children. Shifts in attendance were analysed using binary logistic regression on data from the 2000 and 2005 Integrated Household Living Conditions Surveys. The results show that although the policy has been very successful, the objective has not been achieved. We find a strong effect of the sibling position of the child in the household and its relation to the household head. Substantial numbers of orphans/foster children in Rwanda do not profit from the free education policy and part of the children leave before completing school, in particular girls. Free education is only one step towards a more equitable distribution of educational opportunities.

"Education is the most powerful weapon which you can use to change the world" Nelson Mandela

\section{Introduction}

Most developing countries will probably achieve universal enrolment in primary education for boys and girls in 2015 and will thus meet Millennium Development Goal 2. This, however, does not apply to countries in sub-Saharan Africa. Although they are making impressive progress, there is still a long way to go (see [1]) as they started off farthest from the desired target (see [2]). Rwanda is one of the few subSaharan countries where the gap between objective and result is very small (see [3]). In Rwanda, the enrolment rates have been historically high; at 90 percent, the challenge is to identify and help the last 10 percent of the school-age children that is yet to be enroled in primary school (see [4]). The Rwandan government targeted achieving universal primary education in 2010, and nine years of basic education for all children in 2015. As stated in its Vision 2020 policy document (see [5]), the government aims to transform Rwanda's agricultural-based economy into a knowledgebased economy, for which human resource development is of vital importance. The government emphasises gender equity in all segments of society and the economy, meaning that boys and girls should equally enrol in education.

Several measures have been taken to implement this policy. One was the abolition in 2003 of fees for primary education, which removed one of the obstacles to accessing education. According to Grogan [6], the elimination of school fees is a recent phenomenon in Africa because Malawi eliminated fees in 1994, Uganda in 1997, Tanzania in 2000, and Cameroon, Burundi, Ghana, Rwanda, and Kenya in 2003. In all countries in which UPE (Universal Primary Education) was instituted, the elimination of the direct costs of schooling created an instantaneous large increase in school enrolment (see $[6,7]$ ). The aggregate increases in enrolment 
after the elimination of fees reflect both increases in school attendance among the primary school-age population and among adults and teenagers attending school for the first time (see [6]). In opposite to these results, Bold et al. [8] recently found that the nationwide abolition of public school fees in Kenya in 2003 did not lead to an increase in net public enrolment rates, but rather led to a dramatic shift toward private schooling.

Our contribution to the debate on achieving universal primary school attendance has three objectives: to investigate who have profited from the free education policy in Rwanda, to discover remaining barriers to school attendance in primary education, and to determine which groups of children still fall by the wayside and should be targeted by future policies. We therefore constructed two datasets of individual, household, and community characteristics taken from the 2000-2001 and the 2005-2006 Enquête Intégrale sur les Conditions de Vie des ménages (EICV; Integrated Household Living Conditions Survey), which allowed us to compare the situation before and after the abolition of primary school fees established in September 2003. (The objectives of the EICV are to provide information on poverty and living conditions in Rwanda and to monitor changes over time as part of the ongoing monitoring of the Poverty Reduction Strategy and other government policies. In Rwanda, the EICV is a nationally representative household survey and is carried out once every five years, with EICV1 having been carried out over twelve-month period in 2000/2001 (6420 households) and was repeated with slight modifications in 2005/2006 (6900 households). The content of the EICV2 questionnaire is broadly similar to that of the previous survey.) This period also marks the return of political stability in Rwanda and of positive socioeconomic performance, factors that are important for a successful implementation of education policies (see $[9,10]$ ). We first present a theoretical elaboration of the constraining and enabling factors for the school attendance of girls and boys in primary education. This is followed by a brief introduction to the reconstruction of the educational system in Rwanda, as well as subsections on data, methodology, and selected variables. We then present and discuss the results of the modelling. We end the paper with our conclusions and several policy implications.

\section{Barriers to and Inducements for Primary School Attendance}

The assumption that poor parents/child caretakers are responsive to reductions in school costs can be linked to various socio-economic theories. Departing from the home economics model and the human capital framework (see [11-13]), it can be argued that poor parents/caretakers make a tradeoff between the direct and indirect costs of schooling and the benefits of child labour for the child and the family. (We refer to all reproductive and productive work of children.) Admassie [14] highlighted that uninterrupted school attendance reduces the time the child has for work at home or in the labour market.
Even moderately poor parents with land to work or a business to run keep their children at home instead of hiring external labour (see [15]). In such cases, the opportunity costs of time spent at school are high. In this approach, poverty and a lack of financial resources are seen as barriers to school enrolment and ongoing attendance. The number of hours that children work determines their school attendance: children who work long days on tea plantations or in brick factories cannot attend school (estimate for Rwanda: 400,000 child workers, of whom 120,000 were involved in the worst forms of child labour and 60,000 were domestic workers (see [16])), while children who do domestic or productive work for only a short time each day, or who work seasonally or only when needed, can. (ILO defines child labour by the effect it has on the child. In brief, the work or activities done by children should not interfere with their education or harm their physical or mental health (see [17]).) Besides, parents in subsistence-oriented rural communities often think that it is more important to involve children in economic activities and equip them with the basic life skills for future survival than send them to school for formal education (see $[14,18]$ ).

The absence of a demand for skilled labour, particularly in rural areas, contributes to this and has been identified as a contextual labour market condition that influences the educational decisions of parents (see $[12,19,20]$ ).

The assumption that poor parents need to be encouraged to send their daughters to school is related to the gendered division of labour within the household and to adverse cultural practices in society and the labour market (see $[12,19,21])$. Girls are given domestic chores because their parents want to train them to become good future wives and mothers. Persistent discrimination against girls may also mean that parents, particularly in rural areas, do not attach the same value to educating their daughters as they do to their sons (see [21, 22]). Girls leave the family earlier than boys to marry, after which the fruits of their labour go to their families-in-law. Investments in the education of girls also give lower returns in a labour market where women earn less than men (see [20]). Thus, besides poverty, labour market conditions, gender roles, and cultural practices can also be barriers to enrolment and attendance.

The number of siblings and the sibling position of a child within the household can also inhibit ongoing school attendance, as a result of resource dilution (see [12]) and sibling complementarity (see [15]). Unless there is increased income, the addition of another child results in less real income per household member: the share for basic needs such as food and clothes in the available income per child increases at the expense of the financial means available for education (see $[23,24])$. This can imply that one or more children have to drop out or are kept away from school to enable a brother or sister to enrol. Instead of going to school, these children do domestic chores, work in the family business, or are sent out to work. The larger the number of siblings, the higher the probability that a child enrols later, repeats classes, and/or drops out earlier (see [23]). The presence of young children in households has a negative effect on attendance of older children. Conversely, attendance of school-age children is higher if the household 
has members between 14 and 18 years of age (see $[12,25])$. It also turned out that especially girls suffer from sibling complementarity. The presence of older sisters in one's sibling group has a particularly strong positive effect on schooling, indicating that these older girls are withheld from school to free up or generate resources for their younger siblings' education (see [26]).

Another barrier is the lack of parental support: children living in households without their natural parents are more often deprived of this support (see [27]). There is evidence that orphans and foster children are less likely to be enrolled in school than children who live with their biological parents (see $[28,29]$ ). Thomas [30] confirms this finding for Rwanda and also reports that the extent of schooling deprivation of orphans depends on their family relation to the caretakers, the household type (single or double headed), and the gender of the household head. These relationships are rather complex. Orphans, for instance, are more disadvantaged in a household headed by a couple than in a single-headed household, contrary to the situation of children who live with natural parents. Taking care of children below primary school age is supposed to be an impediment to the school enrolment of particularly full and maternal orphans (see [30]). Case and Ardington [31], Evans and Miguel [32] also concluded that there is a substantial decrease in school participation after the death of a parent and that the death of the mother is more detrimental than that of a father, as male-headed household will more often rely on children for household chores. The impact of household type and gender of the household head on children's education achievements is again partly linked to poverty, as femalemanaged households have less resources than households managed by a couple or male head (see $[33,34]$ ).

However, it can also be linked to effects of inter-generational education concern (transmission of resources) and the gender aspect therein. Educated parents understand the importance of schooling and are more willing to allocate resources for the education of their children. According to Glick and Sahn [35], mother's education has a positive impact on the education of daughters, while father's education favours the education of both sons and daughters. Thus, the presence of both parents in the household as well as having educated parents promotes the school attendance of the children.

The poverty index may not be a sufficient indicator of the purchasing power of a household, as in many African societies transfers between relatives frequently help poor families to overcome their financial problems. In subSaharan Africa, fosterage and the extended-family system redistribute resources across families in ways that buffer educational inequality (see $[23,36]$ ).

School attendance is also linked to other factors, such as place of residence, availability and accessibility of schools, and quality of education. Parents consider low-quality education a waste of time (see [13]), while large distances to school can be a constraint particularly for very young children and girls (see $[4,37,38]$ ). There are differences in school attendance between rural and urban children (see [1]). These effects, however, relate to wider rural and urban differences, such as educational level of parents, labour market conditions, and household income (see [20,39]). To get a clear picture of the barriers to primary school attendance, to explore those who profited of free education and to identify deprived groups of children, geographical and community variables as well as socio-economic and cultural variables at household level must be taken into account.

\section{Reconstruction of the Educational System}

Rwanda's achievements in the field of enrolment in primary education are remarkable. Years of unrest and civil war, which culminated in the 1994 genocide and massive population movements, left Rwandan society disrupted and the country's infrastructure destroyed or heavily damaged (see $[40,41])$. The people, and particularly the children, were severely traumatised (see [42]).

After 1994 the new government immediately decided to make the reconstruction of the educational system a spearhead of policy. Schools had to be built or rebuilt (only 648 of the country's 1836 schools were still operational) and teachers had to be trained and reintegrated, as many teachers had been killed, were now living abroad as refugees, or were displaced within the country. It was estimated that more than half of all qualified primary school teachers were unavailable (see [43]). In addition, the population had to be convinced that schools were safe places again. A large number of Rwandan schools, although financed by the government, are linked to religious institutions, in particular the Roman Catholic Church (see $[4,41]$ ). During the massacres, people had believed that schools and churches were safe havens, but mass killings had occurred in those places.

Finally, special attention had to be paid to the many vulnerable children who had lost one or both parents. (Prevalence of HIV/AIDS also added to this situation.) Rwanda has one of the world's highest rates of orphanhood (see $[30,44]$ ). It was estimated that 85,000 households were headed by a child, $90 \%$ of them girls, when the hostilities came to an end (see $[43,45])$. As more men than women were killed, fled the country, or became prisoners accused of participating in the killings, the number of female-headed households increased. For the children in such households, going to school was often not an option, given the financial constraints and household chores they had to do, which included regular trips to prison to feed their confined parents (see [46]). In 2000, of all children of primary school age (713 years), slightly less than $40 \%$ had only one or no parents at home (see [4]).

By gradually increasing the budget for education to $25.6 \%$ of total spending in 2001 (however, the share allocated for primary education decreased from $70 \%$ to $45 \%$ in favour of tertiary education during the same period), the government was able to reconstruct the educational sector so well that it has been praised by international institutions such as the World Bank and UNESCO. Net enrolment in primary education exceeded $90 \%$, gender equity in this enrolment was nearly accomplished, and the deprivation of orphans was drastically reduced (see $[4,43])$. With regard 
to survival to the end of the cycle, Rwanda's performance is respectable: its estimated 73 percent compares well with the rate in other low-income countries and with its own record of 44 percent in 1990-1991. Yet this rosy situation is unlikely to persist, given the exceptionally high rate of grade repetition in the system-about 34 percent in 2000-2001, or more than three times that of a decade earlier (see [4]).Over 2000 schools were operational, although only half of them could be called "permanent structures." The percentage of qualified teachers was expanded substantially, but double shifting at schools was necessary to meet the demand for education; consequently, the teacher pupil/ratio was high and increasing.

The Rwandan government and its principal development partners in the education sector (UK, USA, Netherlands, Belgium, Sweden, and Germany) concluded that extra efforts were necessary to achieve MDG 2 and to improve the quality of education. According to the Poverty Reduction Strategy Paper (2002), 27\% of children of primary school age were not attending classes regularly. Completion rates for primary education were below 50\% and considerably fewer girls than boys took the final examinations (see $[22,43]$ ).

To improve access to education, the New Constitution (which was adopted in 2003) made education at the primary level free and mandatory for all children. Primary school fees of RWF 300 (RWF 300 per term is just less than \$2 per year ( $\$ 1$ = RWF 537 in Oct. 2003), a small sum compared to the cost of a school uniform and educational material $(\mathrm{RWF}=$ Rwandan Francs)) per term were abolished and replaced by a capitalisation grant to the schools, and several pilot schemes started to provide school lunches and run school farming programmes to encourage households to enrol their children. In 2002, the UN World Food Programme (WFP) launched a school canteen and food-for-education programme in food-insecure districts in the southern and eastern provinces. In collaboration with the government and several donors, this programme provided meals to 160,000 pupils for 4 years and gave 28,800 girls in grades 4 through 6 a monthly take-home ration of vegetable oil. The sale of this oil was expected to cover school costs and increase school attendance by girls (see [47]).

Several ministries set about tackling the issue of the inequality of girls and orphans in school attendance. For example, the Ministry of Local Government, Information and Social Affairs, together with UNICEF and the Ministry of Education, formulated the National Policy for Orphans and Other Vulnerable Children (NP-OVC), which emphasised the integration of OVCs and gender issues as important policy targets in development programmes, the national budget, and poverty reduction strategies (see [48]). Special funds for genocide victims made it possible to improve the living conditions of this section of the population.

Despite the progress, the quality of the primary school system was far from perfect. According to the IMF [49] in its 2003 country annual report, the quality of primary education in Rwanda suffered from a shortage of qualified teachers, a heavy curriculum, and a lack of appropriate educational material. The availability of schools also allowed room for improvement (see [4]).

\section{Data and Methodology}

The 2000 and the 2005 Integrated Household Living Conditions Surveys (hereafter EICV) conducted by the National Institute of Statistics for Rwanda provide sociodemographic data on the members of 13,320 households (a household generally consists of a group of people living in the same accommodation and recognising one person as its head; it may include related and unrelated members and range from a single individual to multiple families) and on the households' services and amenities. According to Megil [50], the EICV is approximately self-weighting within a stratum. The basic weight for each sample household was equal to the inverse of its probability of selection (calculated by multiplying the probabilities at each sampling stage).

The sampling frame of cells within each stratum had been ordered geographically in a serpentine manner before the segments were selected systematically with probability proportional to size (PPS) where the measure of size for each segment/cellule was based on the number of households from the sampling frame; sample households are selected at the second stage within each segment/cell (see [51]).

The dependent variable in our analysis (children in the age category 8-14 years who had not yet completed primary education at the time of the survey) was taken from these two datasets. (The official entrance age for lowest level education in Rwanda is 7 years. The structure of Rwandan education system is 6-year primary cycle, a 3-year common basic program (TC-lower secondary) cycle, a 3year upper secondary cycle, and a 4-year higher education cycle in most fields. As the question regarding attendance was asked on previous 12 months, during the survey, the 7year-old children for primary enrolment were 8 years and the 13-year-old children for grade 6 of primary level were 14 years old during the surveys period. ILO [16] reported that the minimum age for apprenticeship is 14 years in Rwanda.) The children were identified by "age," "highest level of education attained" and "having or not attended school during the 12 months preceding the survey." (We did not exclude children who had missed only some classes.) Of the 11,199 cases appropriate for our study, 50.4\% were collected during the 2000 survey and $49.6 \%$ during the 2005 survey. Only $2 \%$ (228) of the target children had already completed primary school (the $2 \%$ (119 cases in $2000 / 01$ and 109 cases in 2005/06) who completed primary school were excluded in our analysis because some of them were attending secondary school (when our analysis focused on primary or dropped out after completing primary school). The decline in completion from 119 in 2000 to 109 in 2005 is maybe due to a strong increase in enrolment because this is similar to the Boockmann [17] estimates for Tanzania), $89.9 \%(10,268)$ were still attending primary school, and $8.1 \%$ (931) had not attended school during the 12 months preceding the survey.

As the objective was to explore who profited from the free education policy introduced in September 2003, a separate analysis was made for $2000 / 01$ and 2005/06, respectively before and after the free education policy. Besides the combined set was used to check if the changes between 
the two years were significant by including interaction effects with the variable year of the survey.

A logistic regression analysis was carried out to verify the underlying reasons for not attending school. The model describes the log odds that a child aged 8-14 had attended school in the year preceding the EICV of 2000 or 2005. It presents the relative influence of the independent variables on the odds of being attending primary school: a negative $\beta$ coefficient means that the odds are reduced. The data available for our analysis did not allow the inclusion of quality of the school in terms of educational materials or quality of the teaching staff (only data on the quality of the school premises were available) as a barrier to school attendance, but distance to school was taken into account as a geographic factor. Place of residence was used as an indicator of school facilities and the returns (labour market conditions) on education costs. To measure the differential crowding-out effect of having younger siblings for boys and girls we constructed a combined variable of gender and sibling position, bearing in mind that children without siblings could be a mixed group of foster children, afterthoughts, the only child or the only surviving child.

Although the data also contains information on the number of hours spent at household chores, we did not include that variable in the model to avoid endogeneity. It is plausible that to keep a child away from school and putting them to work for several hours a day is basically one decision made by the parent.

\section{Descriptive Analysis of the Research Population}

Table 1 reports the descriptive statistics of the independent variables which start with the variables at community level (place of residence and distance to school), followed by variables at the household level and then variables at the individual level. Table 1 presents children who have or have not been to school during the 12 months preceding the surveys according to year of the survey. Rwanda is a predominantly poor, rural society: most people live in scattered homesteads in the hills and agriculture is their main activity. These features are reflected in the characteristics of the children in the datasets: four out of five live in the countryside, and two out of three are member of a household of cultivators, fisher folk, or cattle keepers. Thirteen percent of school-age children from rural areas were out of school in 2000 and $12 \%$ of those coming from a farm. Between 2000 and 2005, however, these percentages decreased partly as a result of the abolishment of fees and a massive program of poverty reduction. Children in urban centres are privileged compared to children in rural areas in terms of the availability (particularly concerning secondary, higher education and diversity of primary education) and quality of schools and diversified future job opportunities. The better endowed schools are in the capital. According to the World Bank [4] Report on Education in Rwanda, children in half of the rural households have to walk for more than 30 minutes to get to school; in urban centres, this applies to only
$20 \%$ of households. The bank experts emphasised that the differences are even more pronounced within provinces.

We divided distance to school into three groups: nearly half of the children in the total survey sample lived in communities (a community generally means a "cell" in the Rwandan administrative structure, because the question on distance to school was put to the coordinator of the cell. A cell (Akagari in Kinyarwanda) is the smallest administrative unit in Rwanda and hence closest to the people) with at least one primary school (distance $0.5 \mathrm{~km}$ or less), a second lived in communities with at least one primary school in a neighbouring community (0.5-2 km distance), and a third had more than a 30 -minute walk to school $(<2 \mathrm{~km})$. The nonattendance of children living at a distance to school of more than $2 \mathrm{~km}$ was $15 \%$ in 2000 and 6\% in 2005.

Rwanda is a low-income country: it had a per capita GDP of $\$ 200$ at the beginning of the millennium. More than half of the population lived on an income below the poverty line; according to the Ministry of Finance and Economic Planning (see $[53,54]$ ), these Rwandans consumed less than RWF 250 $(<\$ 50$ cents) per adult equivalent per day. The extremely poor had to get by on less than RWF $125(<\$ 25$ cents) in 2000 and RWF 175 (\$30 cents) in 2005 per day. In these poor households, over $70 \%$ of total consumption is spent on food, which illustrates the lack of means left for clothes, housing, school fees, and uniforms (up to RWF 11,000 = \$21) or health insurance cards (RWF 1000 approximately less $\$ 2$ per family member). School attendance has gone up in each category between 2000 and 2005, but particularly in the category of extremely poor.

Solidarity between family members in Rwanda is high, as shown by the large number of households that had received transfers in cash or kind during the 12 months preceding the surveys. For the two periods, the households of $70 \%$ of the children had received assistance from outside. Nearly half of the households had received transfers (transfers have three components: transfers in cash, in food, in other goods, and miscellaneous. The transfers are coming from parents, son/daughter, brother/sisters, spouse/wife, in-laws, other family, or not related persons. The senders are living in the same countryside, Kigali Capital, other centers, other countryside, adjacent countries and few of them are living in other African country or in rest of the world. Most of the transfers are annually or monthly and only few of them are on a daily or weekly basis) amounting to more than RWF 5000 (less \$10) per year. (RWF 5000 is just less $\$ 10$ per year ( $\$ 1=$ RWF 537 in Oct. 2003).) Remarkably, nonpoor households received assistance more often than extremely poor households, and the value of rural to urban flows was on average less than a quarter of those in the opposite direction.

The impact of the genocide and the prevalence of HIV/AIDS among the adult population are reflected in the large number of children with no parents (16\%). Siaens et al. [29] stated in 2003 that as the country has emerged out of conflict, the AIDS pandemic has begun to take a heavy toll of human lives, contributing significantly to adult mortality. The children with no parents were either full orphans or lived with relatives for reasons other than the death of their 
TABLE 1: Descriptive statistics on the independent variables influencing the nonattendance at school for children aged 8-14 years during EICV 2000/01 and 2005/06.

\begin{tabular}{|c|c|c|c|c|}
\hline \multirow{2}{*}{ Variables } & \multicolumn{2}{|c|}{$2000 / 01$ survey } & \multicolumn{2}{|c|}{ 2005/06 survey } \\
\hline & Observations & Not attend school (\%) & Observations & Not attend school (\%) \\
\hline Total & 5.649 & $678(12)$ & 5.550 & $253(5)$ \\
\hline \multicolumn{5}{|l|}{ Residence } \\
\hline Rural & 4.749 & $613(13)$ & 4.395 & $200(5)$ \\
\hline Other urban centre & 378 & $41(11)$ & 562 & $30(5)$ \\
\hline Kigali & 522 & $24(5)$ & 593 & $23(4)$ \\
\hline \multicolumn{5}{|l|}{ Distance to school } \\
\hline$<1 / 2 \mathrm{~km}$ & 2.402 & $235(10)$ & 2.965 & $136(5)$ \\
\hline $1 / 2-2 \mathrm{~km}$ & 1.887 & $235(12)$ & 1.572 & $61(4)$ \\
\hline$>2 \mathrm{~km}$ & 1.360 & $208(15)$ & 1.013 & $56(6)$ \\
\hline \multicolumn{5}{|l|}{ Occupation household head } \\
\hline Farm activities & 5.106 & $634(12)$ & 2.170 & $95(4)$ \\
\hline Nonfarm activities & 543 & $44(8)$ & 3.380 & $158(5)$ \\
\hline \multicolumn{5}{|l|}{ Poverty* } \\
\hline Nonpoor & 2.060 & $166(8)$ & 2.190 & $86(4)$ \\
\hline Poor & 1.075 & $129(12)$ & 1.112 & $48(4)$ \\
\hline Extremely poor & 2.514 & $383(15)$ & 2.248 & $119(5)$ \\
\hline \multicolumn{5}{|l|}{ Financial transfers received } \\
\hline None & 1.623 & $189(12)$ & 951 & $44(5)$ \\
\hline$<$ RWF $5000(<\$ 10)$ & 2.606 & $330(13)$ & 1.674 & $92(6)$ \\
\hline$>$ RWF $5000(>\$ 10)$ & 1.420 & $159(11)$ & 2.925 & $117(4)$ \\
\hline \multicolumn{5}{|l|}{ Education of household head } \\
\hline None & 4.167 & $515(12)$ & 1.976 & $78(4)$ \\
\hline $1-5$ years primary education & 512 & $60(12)$ & 1.836 & $63(3)$ \\
\hline Primary school + & 970 & $103(11)$ & 1.738 & $112(6)$ \\
\hline \multicolumn{5}{|l|}{ Presence of parents in household } \\
\hline Both & 2.756 & $282(10)$ & 3.264 & $94(3)$ \\
\hline Father only & 259 & $49(19)$ & 211 & $19(9)$ \\
\hline Mother only & 1.620 & $196(12)$ & 1.299 & $62(5)$ \\
\hline Neither & 1.014 & $151(15)$ & 776 & $78(10)$ \\
\hline \multicolumn{5}{|l|}{ Age } \\
\hline $8-10$ years & 2.293 & $85(4)$ & 2.492 & $43(2)$ \\
\hline $11-12$ years & 1.627 & $171(11)$ & 1.576 & $64(4)$ \\
\hline $13-14$ years & 1.729 & $422(24)$ & 1.482 & $146(10)$ \\
\hline \multicolumn{5}{|l|}{ Gender and position among sibling } \\
\hline Male with old sibling & 908 & $127(14)$ & 992 & $62(6)$ \\
\hline Female with old sibling & 984 & $123(13)$ & 975 & $43(4)$ \\
\hline Male with old and young sibling & 1.533 & $171(11)$ & 1.561 & $53(3)$ \\
\hline Female with old and young sibling & 1.577 & $150(10)$ & 1.605 & $58(4)$ \\
\hline Male with young sibling & 59 & $9(15)$ & 25 & $5(20)$ \\
\hline Female with young sibling & 136 & $26(19)$ & 19 & $6(32)$ \\
\hline Male without sibling & 224 & $38(17)$ & 181 & $16(9)$ \\
\hline Female without sibling & 228 & $34(15)$ & 192 & $10(5)$ \\
\hline \multicolumn{5}{|l|}{ Time spent on chores per week } \\
\hline$<14$ hours & 4.535 & $462(10)$ & 3.266 & $148(5)$ \\
\hline$>14$ hours & 1.114 & 216 (19) & 2.284 & $105(5)$ \\
\hline
\end{tabular}

* The poverty line was calculated on the basis of the level of household consumption including purchases but also on consumption from other sources like own production and payments received in kind. The approach used follows standard international practices by adjusting for differences in prices faced by households (price deflator) and by taking into account the household composition (household size measured in terms of adult equivalents). Given the prices in January 2001, the poverty line was set at RWF 64,000 (\$120) per adult per year, and an extreme poverty line (below which households could not even afford the basic food consumption basket, even without spending anything on nonfood items, was RWF 45,000 (\$85) per adult per year. For January 2006 prices these poverty lines translate into RWF 90,000 (\$170) and RWF 63,500 (\$120) per adult per year, respectively (see [52]). 
parent(s). Fostering out children in order to enable them to go to primary school is not a common practice in Rwanda, like in some countries in West Africa, and most of them will be orphans. They are expected to be more deprived from education than children in other households. The variable presence of parents in the household together with the educational level of the head of the household was used to test whether girls and boys benefit differently from educated parents/caretakers. More than half of the children came from households with an uneducated head. In a quarter of the cases, the head had at least completed primary school. Fifteen percent and ten percent of double orphans were not at school for 2000 and 2005 while the dropout was $10 \%$ and $3 \%$ for nonorphans in the same years. Finally, the older the child, the higher the probability to drop out, as is clearly illustrated in the distribution according to three age groups.

\section{Results}

We built separate models for the 2000/01 and 2005/06 datasets, because the two years characterised the periods before and after the introduction of the free education policy in Rwanda. To find out whether children with or without siblings had gained significantly higher chances of attendance over time, we combined gender and the position among siblings in the household as one independent variable. This helped to establish whether the position among siblings has a differential impact on attendance for boys and girls.

An evaluation of other attendance constraining factors during the period 2000-2005 allowed us to identify groups of children who profited from the free education and those who need specific attention of the government to fully achieve MDG 2. We expected negative effects of the presence of younger siblings, living on a farm and of a large distance to school. Positive effects on education-according to the literature-could be, living in urban areas, educational level of the household head, and income transfers from relatives. However, some of the constraining and enabling factors turned out not to be significant in their contribution to the school attendance and were dropped from our final model presented in Table 2. The factors that did not show up are, residence area, education level of the household head and his/her occupational status. Even after controlling for distance to school, we expected a positive effect of living in urban areas (and especially in the capital) rather than rural areas, because urban labour markets are more diversified and offer a better return on investments in educating one's children. However the models show that children living in Kigali do not have higher odds ratios than children from rural areas. The same holds for the educational level of the head of the household, or his/her economic activities. We expected that people with a better education would be keener to send their children to school, like parents who do not work in the agricultural sector. However, the results of all these analyses turned out not to be statistically significant.

The idea that income transfers between family members promote school attendance is not confirmed by our analysis. The results are not significant and the odds ratios in both
2000/01 and 2005/06 are close to 1 . We checked whether households with school-aged children received more transfers than others, but again the effects were very limited. Transfers help to alleviate the worst poverty in general, but were not used specifically to have children attending primary school.

To investigate the robustness of the final model with respect to possible interaction effects, we tested the interaction effects of gender and presence of parents, gender and poverty, and gender and distance to school. None of these showed up as significant in the model. To test the hypothesis that the introduction of free education in 2003 in Rwanda did lead to improved school attendance of the poor in particular, the right hand column of Table 2 shows whether the parameters are significantly different between the years.

The constant in each model reflects the starting point for the 2000/01 and 2005/06 surveys in our reference category of nondeprived boys aged 8-10 years from nonpoor, complete families, with older sibling(s) and living at a distance to school of less than $0.5 \mathrm{~km}$ away. The $\operatorname{Exp}(\mathrm{B})$ of the constant gives this category's odds of attending primary school. The odds of attending school for boys in this group are 112 to 1 in 2005. Also in 2000, most of the boys in this group went to school, although their odds were lower (55 to 1 ) compared to 2005.

The other variable's $\operatorname{Exp}(B)$ give the odds ratios for categories that deviate from the reference category. Multiplying these by the constant gives an idea of their odds of attendance. Table 2 shows that in 2000 compared to the reference category, coming from a poor or an extremely poor family reduced the odds of attending school, the ratios are 0.646 and 0.471 , respectively, for children from poor and extremely poor families making their odds 36 to 1 and 26 to 1 . In 2005 (Table 2) the odds for children of poor families are equal to those from non-poor families. The odds for the children from extremely poor families were also better in 2005; their odds ratio in that year is of the same magnitude as the ratio for children from poor families 5 years before.

School attendance of the poor and very poor clearly improved in the period 2000-2005. Despite the policy to pay specific attention to vulnerable children and particularly orphans, the models show that the attendance of children who had lost both parents did not improve between 2000 and 2005. The odds ratios are smaller in 2005. Orphans even lagged significantly further behind other children in 2005 than in 2000 .

The gender of the child combined with its sibling position did have a significant impact on school attendance, and again these effects are stronger in 2005 than in 2000.

Being the youngest in the household has the expected positive effect at least for girls, although the odds ratio is not significant in 2000, but it is in 2005. Being the oldest has the expected negative effect on school attendance for both boys and girls but more so for girls than for boys. The effect is much stronger in 2005, the odds of attending school being 172 to 1 for girls that are the youngest and 14 to 1 for those being the oldest in the family. Despite the successful efforts of the Rwandan administration to promote gender equality 
TABLE 2: Binary logistic regression model of school attendance in 2000/01 and 2005/06.

\begin{tabular}{|c|c|c|c|c|c|c|c|c|c|c|c|}
\hline \multirow{2}{*}{ Variables in the equation } & \multicolumn{5}{|c|}{ 2000/01 survey } & \multicolumn{5}{|c|}{ 2005/06 survey } & \multirow{2}{*}{ Shift } \\
\hline & $B$ & S.E. & $\mathrm{df}$ & Sig. & $\operatorname{Exp}(B)$ & $B$ & S.E. & $\mathrm{df}$ & Sig. & $\operatorname{Exp}(B)$ & \\
\hline Child of nonpoor family (Ref. Cat.) & & & 2 & 0.00 & & & & 2 & 0.01 & & \\
\hline Child of poor family & -0.44 & 0.13 & 1 & 0.00 & 0.65 & -0.08 & 0.19 & 1 & 0.69 & 0.93 & $* * *$ \\
\hline Child of extreme poor family & -0.75 & 0.11 & 1 & 0.00 & 0.47 & -0.46 & 0.16 & 1 & 0.00 & 0.63 & $* * *$ \\
\hline Father and mother present (Ref. Cat.) & & & 3 & 0.00 & & & & 3 & 0.00 & & \\
\hline Father only present & -0.71 & 0.18 & 1 & 0.00 & 0.49 & -1.17 & 0.27 & 1 & 0.00 & 0.31 & \\
\hline Mother only present & -0.11 & 0.11 & 1 & 0.29 & 0.89 & -0.40 & 0.18 & 1 & 0.03 & 0.67 & \\
\hline Neither & -0.40 & 0.17 & 1 & 0.02 & 0.67 & -1.74 & 0.22 & 1 & 0.00 & 0.18 & $* * *$ \\
\hline Male with old sibling (Ref. Cat.) & & & 7 & 0.14 & & & & 7 & 0.00 & & \\
\hline Female with old sibling & 0.19 & 0.14 & 1 & 0.18 & 1.21 & 0.42 & 0.21 & 1 & 0.04 & 1.53 & \\
\hline Male with old and young siblings & -0.02 & 0.14 & 1 & 0.92 & 0.99 & -0.07 & 0.21 & 1 & 0.74 & 0.93 & \\
\hline Female with old and young siblings & 0.14 & 0.14 & 1 & 0.32 & 1.15 & -0.17 & 0.21 & 1 & 0.42 & 0.84 & \\
\hline Male with young sibling & -0.30 & 0.41 & 1 & 0.47 & 0.74 & -1.71 & 0.57 & 1 & 0.00 & 0.18 & $* * *$ \\
\hline Female with young sibling & -0.57 & 0.28 & 1 & 0.04 & 0.57 & -2.10 & 0.55 & 1 & 0.00 & 0.12 & $* * *$ \\
\hline Male without sibling & -0.24 & 0.25 & 1 & 0.34 & 0.78 & 0.55 & 0.33 & 1 & 0.09 & 1.74 & \\
\hline Female without sibling & 0.06 & 0.26 & 1 & 0.82 & 1.06 & 1.23 & 0.38 & 1 & 0.00 & 3.41 & $* * *$ \\
\hline Distance less $0.5 \mathrm{~km}$ (Ref. Cat.) & & & 2 & 0.00 & & & & 2 & 0.08 & & \\
\hline Distance $0.5-2 \mathrm{~km}$ & -0.19 & 0.10 & 1 & 0.07 & 0.83 & 0.25 & 0.16 & 1 & 0.13 & 1.28 & $* * *$ \\
\hline Distance higher than $2 \mathrm{~km}$ & -0.40 & 0.11 & 1 & 0.00 & 0.67 & -0.19 & 0.17 & 1 & 0.26 & 0.83 & \\
\hline 8 to 10 years & & & 2 & 0.00 & & & & 2 & 0.00 & & \\
\hline 11 to 12 years & -1.09 & 0.14 & 1 & 0.00 & 0.34 & -0.82 & 0.20 & 1 & 0.00 & 0.44 & \\
\hline 13 to 14 years & -2.14 & 0.13 & 1 & 0.00 & 0.12 & -1.86 & 0.18 & 1 & 0.00 & 0.16 & \\
\hline Constant & 4.00 & 0.19 & 1 & 0.00 & 54.75 & 4.71 & 0.26 & 1 & 0.00 & 111.48 & \\
\hline
\end{tabular}

Hosmer-Lemeshow Test chi-square $=8.988, \mathrm{df}=8, P=0.343$ for 2000/01 and Hosmer-Lemeshow Test chi-square $=12.123, \mathrm{df}=8, P=0.146$ for $2005 / 06$. The right hand column shows whether the differences over time are significant at the $5 \%$ level.

in all aspects of society, girls are still valued and treated differently from boys within the family.

The negative effect of distance to school was estimated in 2000 with a ratio of 0.669 (37 to 1 ) while its significance disappeared in 2005. However, for the distance 0.6 to $2 \mathrm{~km}$ the improvement in attendance between 2000 and 2005 was significant, pointing at the impact of the reconstruction of school buildings policies.

In order to access secondary education, one needs to complete primary education. The last variable in our model shows that this is still problematic in Rwanda. Drop-out rates rise sharply after the age of 10 , which can be seen from the very low odds ratios of attendance of 11 to 12 year olds and particularly 13 to 14 year olds. For the latter group, the ratios are 0.118 for 2000 (6 to 1) and 0.155 for 2005 (18 to 1$)$. The test whether variables had significantly different effects between the years shows significant improvement in attendance for both the poor and the very poor and for those living at the medium distance from school. The more negative outcome for children from one-parent families and orphans is only significant for the orphans. The stronger negative effect of having young siblings in 2005 also differs significantly from the effects in 2000 , for both boys and girls. Females without sibling have clearly improved in attendance.

The conclusion here is that although the government has been very successful in getting children to school, it is less successful in keeping them in school until they have completed their primary education. There might be several explanations for this. It could be a cohort effect, as the higher age group might have left school at a time when the conditions for enrolment were less favourable. Returning to school is harder than staying at school. If this is true, the problem will fade away. However, it could also be that the higher economic value of older school-aged children (an effect not captured by our other variables) leads to a different tradeoff between school and gainful employment. This tradeoff could be influenced by the quality of the educational programme and the added value in the labour market of a completed primary education. This issue calls for further research.

\section{Conclusion, Discussion, and Policy Implications}

In the first few years of the new millennium, the Rwandan government continued to increase the enrolment in primary education of boys and girls in general and of girls from poor families in particular. Our results show that the effort has been very successful for the majority of primary schoolaged children. Nevertheless, the objective had not been achieved fully by 2005 . Foster children and orphans are still being discriminated against. Besides, increased attendance at younger ages to achieve MDG 2 is not sufficient, as some older boys and girls are kept away from school to work 
in or outside the homestead. Extra policy measures and programmes are necessary to facilitate the completion of primary education by children above the age of 10, with specific attention paid to the oldest girls in the family and foster children.

Poverty leading to resource dilution when family size increases and sibling complementarity are probable causes for keeping children away from school and making them work. The elimination of school fees was a first step, but clearly not a big enough one. The estimated costs (2002) of RWF 11,000 (\$21) per child per year were still a great deterrent to enrolling a child in school. Even the Ministry of Education (see [55]) recognised that the main financial support at that time for children attending school is the family $(90.6 \%)$, followed by the state $(4.5 \%)$ and then other organisations. Subsidies for school uniforms for children from extremely poor and incomplete families could be a policy option. Experiments in Kenya illustrated that giving school uniforms to poor children reduced school absenteeism (see [32]). School uniforms could perhaps be bought by schools and loaned to families for a nominal fee. It should be discussed whether the advantages of compulsory school uniforms are more important than achieving full school enrolment and completion in a country that has so many poor parents/caretakers. The World Food Program (WFP) started the school feeding program (SFP) in Rwanda in 2001. In 2005, the Rwanda SFP was targeted to 12 droughtprone, food-insecure districts. Attendance rates in WFPassisted schools increased from 73 percent to 95 percent in 2006 (see [56]). From January 2008 to December 2012, WFP extended its program targeting 290,000 students in 300 schools, at a cost of $\$ 4.5$ million per year. In response to government's policy shift to include free education to nine years of basic education (9YBE), WFP has raised its target to 350,000 across the country. Nutritious food is provided as a daily cooked meal in primary schools, and starting in 2010 WFP also provided a monthly take-home ration of vegetable oil for host families of orphans and vulnerable children (OVC) (see [57]). The Rwandan government aims at the implementation of a general school feeding programme by 2012, when the WFP support (the government partner in feeding school children) will be phased out. The assessment of local production for school meals in Rwanda is the first step towards having parents and local communities taking over WFP school-feeding programmes (see [58]). The latest news on this topic, however, is that-after the ending of the WFP program-schools will ask parents to pay RWF 4700 (around \$8) for a period of 3 months or the authorities will ask a support from residents for the meals distributed at school if the program is to continue (see [59]). As our analyses showed that the very poor have lower odds of attendance, requesting a contribution of parents might introduce a new barrier for this group in particular, and finding ways of exempting them from charges might be called for. Enforcing the laws on compulsory primary education and the prohibition of child labour and apprenticeships by children under the age of 15 who have not completed primary education could possibly also contribute to achieving MDG 2. The education situation of orphans has deteriorated in Rwanda. This is a problem that will not disappear when the victims of the disturbing events of the 1990s have grown up as long as people continue to fall victim to HIV/AIDS. Particularly orphans of parents who died of this disease are stigmatised and receive less community support (see [27]). A grant given to the orphan him- or herself to cover the cost of uniforms and books or as reward for actually attending school would be preferable to providing the orphan's household with general financial support. There are also clear limits to what policies might achieve. Several authors have concluded that when enrolment in primary education is close to universal, as it is in Rwanda, the enabling factors hardly contribute to even higher attendance rates, although they might play a role in the completion of primary school and therefore also in the enrolment in secondary education. Bold et al. [8], Behrman and Skoufias [60] found this to be the case for Kenya and Mexico. In the evaluation of PROGRESA (PROGRESA is a Mexican government program introduced in August1997 as a key component of its poverty alleviation strategy. PROGRESA is an acronym for "Programa de Education, Salud y Alimentacion" or the "Education, Health and Nutrition Program" [61]) in Mexico, Coady [61] found that this programme increased the enrolment rates by $0.74-1.07$ percentage points for boys and $0.96-1.45$ percentage points for girls. However, our analyses showed that constraining factors are of importance to specific groups and policies may be devised to target these groups in particular to increase their efficiency. Yet we are aware that achieving universal completion of primary education depends on more than educational policies. We agree with Buchmann [12] that a lack of added value in the labour market of a completed education might negatively affect the tradeoff between the costs and returns related to older pupils. Education is not just an instrument, but also an outcome of poverty reduction and economic development. Further research into the driving factors for completion rather than just attendance is needed.

\section{Acknowledgments}

The authors would like to express their appreciation to Hewlett Foundation and Netherlands Organisation for Scientific Research for their financial support (Grant no. W07 4020200 ), to the anonymous reviewers for their stimulating comments, and to Jeremy Raynor for language editing.

\section{References}

[1] UN (United Nations), The Millennium Development Goals Report 2010, United Nations, New York, NY, USA, 2010.

[2] W. Easterly, "How the millennium development goals are unfair to Africa," World Development, vol. 37, no. 1, pp. 2635, 2009.

[3] UNDP (United Nations Development Programme), Human Development Report 2010. The Real Wealth of Nations. Pathways to Human Development, UNDP, New York, NY, USA, 2010.

[4] WB (World Bank), Education in Rwanda. Rebalancing Resources to Accelerate Post-Conflict Development and Poverty 
Reduction, A World Bank, Country Study, Washington, DC, USA, 2004.

[5] MINECOFIN (Ministry of Finance Economic Planning), Vision 2020, MINECOFIN, Kigali, Rwanda, 2000.

[6] L. Grogan, "Universal primary education and school entry in Uganda," Journal of African Economies, vol. 18, no. 2, pp. 183 211, 2009.

[7] K. Deininger, "Does cost of schooling affect enrollment by the poor? Universal primary education in Uganda," Economics of Education Review, vol. 22, no. 3, pp. 291-305, 2003.

[8] T. Bold, M. Kimenga, G. Mwabu, and J. Sandefur, "Why did abolishing fees not increase public school enrolment in Kenya?” Working Paper 271, Center for Global Development, Washington, DC, USA, 2011.

[9] K. Banya and J. Elu, "Implementing basic education: an African experience," International Review of Education, vol. 43, no. 5-6, pp. 481-496, 1997.

[10] E.O. Mukudi and E. J. Keller, "Public funding and budgetary challenges to providing universal access to primary education in sub-Saharan Africa," International Review of Education, vol. 56, no. 1, pp. 5-31, 2010.

[11] G. S. Becker, A Treatise on Family, Harvard University Press, Cambridge, Mass, USA, 1991.

[12] C. Buchmann, "Family structure, parental perceptions, and child labor in Kenya: what factors determine who is enrolled in school?" Social Forces, vol. 78, no. 4, pp. 1349-1378, 2000.

[13] P. Jensen and H. S. Nielsen, "Child labour or school attendance? Evidence from Zambia," Journal of Population Economics, vol. 10, no. 4, pp. 407-424, 1997.

[14] A. Admassie, "Child labour and schooling in the context of a subsistence rural economy: can they be compatible?" International Journal of Educational Development, vol. 23, no. 2, pp. 167-185, 2003.

[15] K. Basu and Z. Tzannatos, "The global child labor problem: what do we know and what can we do?" World Bank Economic Review, vol. 17, no. 2, pp. 147-173, 2003.

[16] ILO (International labour Organisation), Child Labour in Africa, Cornell University/International Labour Organisation, Ithaca, NY, USA, 2005.

[17] R. Ravinder, "The child labour in developing countries: a challenge to millennium development goals," Indus Journal of Management \& Social Sciencesno, vol. 3, no. 1, pp. 1-8, 2009.

[18] C. Y. Kim, "Is combining child labour and school education the right approach? Investigating the Cambodian case," International Journal of Educational Development, vol. 29, no. 1, pp. 30-38, 2009.

[19] C. Colclough, P. Rose, and M. Tembon, "Gender inequalities in primary schooling: the roles of poverty and adverse cultural practice," International Journal of Educational Development, vol. 20, no. 1, pp. 5-27, 2000.

[20] L. Ersado, "Child labor and schooling decisions in urban and rural areas: comparative evidence from Nepal, Peru, and Zimbabwe," World Development, vol. 33, no. 3, pp. 455-480, 2005.

[21] M. Q. Dao, "Gender gaps in human capital in developing countries: an empirical assessment," Economics Research International, vol. 2012, Article ID 715419, 8 pages, 2012.

[22] A. Huggins and S. K. Randell, "Gender equality in education in Rwanda: what is happening to our girls?" in South African Association of Women Graduates Conference on "Drop-Outs from School and Tertiary Studies: What Is Happening to Our Girls?", Cape Town, South Africa, 2007, http://www.ifuw.org/rwanda/media/art-education.pdf.
[23] P. M. Eloundou-Enyegue and L. B. Williams, "Family size and schooling in sub-Saharan African settings: a reexamination," Demography, vol. 43, no. 1, pp. 25-52, 2006.

[24] T. O. Owuamanam and O. Alowolodu, "Education pursuit and Income as correlates of Family size in Ondo State, Nigeria," Journal of Social Sciencesno, vol. 23, no. 2, pp. 123-127, 2010.

[25] B. Boockmann, "The effect of ILO minimum age conventions on child labor and school attendance: Evidence from aggregate and individual-level data," World Development, vol. 38, no. 5, pp. 679-692, 2010.

[26] R. Salem, Is Gender Bias in Education in Education Mediated by Sibling Configuration?: evidence from Egypt, Office of Population Research, Princeton University, Princeton, NJ, USA, 2007.

[27] T. R. Thurman, L. A. Snider, N. W. Boris, E. Kalisa, L. Nyirazinyoye, and L. Brown, "Barriers to the community support of orphans and vulnerable youth in Rwanda," Social Science and Medicine, vol. 66, no. 7, pp. 1557-1567, 2008.

[28] S. Bhalotra, "Child labour in Africa," OECD Social, Employment and Migration Working Paper no. 4, OECD, 2003.

[29] C. Siaens, K. Subbarao, and Q. Wodon, Are Orphans Especially Vulnerable? Evidence from Rwanda, World Bank, Washington, DC, USA, 2003.

[30] K. J. A. Thomas, "Family contexts and schooling disruption among orphans in post-genocide Rwanda," Population Research and Policy Review, vol. 29, no. 6, pp. 819-842, 2010.

[31] A. Case and C. Ardington, "The impact of parental death on school outcomes: longitudinal evidence from South Africa," Demography, vol. 43, no. 3, pp. 401-420, 2006.

[32] D. K. Evans and E. Miguel, "Orphans and schooling in Africa: a longitudinal analysis," Demography, vol. 44, no. 1, pp. 35-57, 2007.

[33] P. Vinck, Rwanda: Comprehensive Food Security and Vulnerability Analysis, WFP and NISR in Strengthening Emergency Needs Assessment Capacity (SENAC), Kigali, Rwanda, 2006, http://zunia.org/uploads/media/knowledge/ Rwanda\%20CFSVA\%20Final\%20Feb_07.pdf.

[34] K. Musick and R. D. Mare, "Recent trends in the inheritance of poverty and family structure," Social Science Research, vol. 35, no. 2, pp. 471-499, 2006.

[35] P. Glick and D. E. Sahn, "Schooling of girls and boys in a West African country: the effects of parental education, income, and household structure," Economics of Education Review, vol. 19, no. 1, pp. 63-87, 1999.

[36] J. F. Kobiané, A. E. Calvès, and R. Marcoux, "Parental death and children's schooling in Burkina Faso," Comparative Education Review, vol. 49, no. 4, pp. 468-489, 2005.

[37] A. Bommier and S. Lambert, "Education demand and age at school enrollment in Tanzania," Journal of Human Resources, vol. 35, no. 1, pp. 177-203, 2000.

[38] Y. Nonoyama-Tarumi, E. Loaiza, and P. L. Engle, "Late Entry into primary school in developing societies: findings from cross-national household surveys," International Review of Education, vol. 56, no. 1, pp. 103-125, 2010.

[39] S. Al-Samarrai and B. Reillya, "Urban and rural differences in primary school attendance: an empirical study of Tanzania," Journal of African Economies, vol. 9, no. 4, pp. 430-474, 2000.

[40] P. Uvin, "Reading the Rwandan genocide," International Studies Review, vol. 3, no. 3, pp. 75-99, 2001.

[41] J. Bridgeland, S. Wulsin, and M. McNaught, Rebuilding Rwanda. From Genocide to Prosperity through Education, Hudson Institute, New York, NY, USA, 2009.

[42] A. Dyregrov, L. Gupta, R. Gjestad, and E. Mukanoheli, "Trauma exposure and psychological reactions to genocide 
among Rwandan children," Journal of Traumatic Stress, vol. 13, no. 1, pp. 3-21, 2000.

[43] A. Obura, Never Again: Educational Reconstruction in Rwanda, UNESCO/International Institute for Education Planning, Paris, France, 2003.

[44] D. De Walque, "Parental education and children's schooling outcomes: evidence from recomposed families in Rwanda," Economic Development and Cultural Change, vol. 57, no. 4, pp. 723-746, 2009.

[45] A. Okech and R. M. Torres, Rwanda: Study of Literacy Needs and Programmes for Youth and Adults, Ministry of Education, Science, Technology and Scientific Research, Final Report, Kigali, Rwanda, 2005.

[46] SCF (Save the Children Fund), Learning From Experience: Children and Violence, SCI, London, UK, 1999.

[47] WFP (World Food Program), Report of the Evaluation of the WFP's Portfolio of Activities in Rwanda, WFP Evaluation Office, OEDE, Rome, Italy, 2004.

[48] MINALOC (Ministry of Local Government, Information and Social Affairs), National Policy for Orphans and Vulnerable Children, MINALOC, Kigali, Rwanda, 2003.

[49] IMF (International Monetary Fund), Rwanda: Poverty Reduction Strategy, Annual Progress Report 2003, IMF, Washington, DC, USA, 2005.

[50] D. J. Megil, Recommandations on Sample Design and Estimation Methodology for the Rwanda Enquête Intégrale sur les Conditions de vie des Ménages 2005, OPM, Kigali, Rwanda, 2005.

[51] NISR, Enquête Intégrale sur les Conditions de vie des Ménages 2005-2006, Study Documentation, NISR, Kigali, Rwanda, 2007.

[52] A. McKay and G. Greenwell, "Methods used for poverty analysis in Rwanda poverty update note," First draft, 2007 http://196.44.242.24/eicv/survey0/data/docs/studies/ rwanda_poverty_analysis_methodological_note_first_draft.pdf.

[53] MINECOFIN, Preliminary Poverty Update Report, Integrated Living Conditions Survey 2005/06, Rwanda Development Indicators, National Institute of Statistics, Kigali, Rwanda, 7th edition, 2006.

[54] MINECOFIN, EICV Poverty Analysis for Rwanda's Economic Development and Poverty Strategy, National Institute of Statistics, Kigali, Rwanda, 2007.

[55] MINEDUC (Ministry of Education, Science, Technology and Scientific Research), Education for All: Plan of Action, MINEDUC, Kigali, Rwanda, 2003.

[56] W. Lamberts, "Hunger: school feeding in Rwanda," 2009, http://voices.yahoo.com/ending-child-hunger-school-feeding -rwanda-2473805.html.

[57] A. Gelli, U. Meir, and F. Espejo, "Does provision of food in school increase girls' enrollment? Evidence from schools in sub-Saharan Africa," Food and Nutrition Bulletin, vol. 28, no. 2, pp. 149-155, 2007.

[58] USDA (United States Department of Agriculture), Assessment of Local Production for School Feeding in Rwanda, Bill and Melinda Gates Foundation with assistance from the WFP, Washington, DC, USA, 2009, http://www.sign-schoolfeeding .org/_dynamic/downloads/Assessment\%20of\%20Local\%20Production\%20for\%20School\%20Feeding\%20in\%20Rwanda .pdf.

[59] A. V. Dusabemungu, Pupils Abandon School Due to Lack of Food, IGIHE.Com-Newspaper, 2012, http://en.igihe.com/ news/pupils-abandon-school-due-to-lack-of-food.html.

[60] J. R. Behrman and E. Skoufias, "Mitigating myths about policy effectiveness: evaluation of Mexico's antipoverty and human resource investment program," Annals of the American
Academy of Political and Social Science, vol. 606, no. 1, pp. 244275, 2006.

[61] D. Coady, Alleviation Structural Poverty in Developing Countries: The Approach of PROGRESA in Mexico, Research Fellow Food Consumption Nutrition Division International Food Policy Research Institute, 2003. 


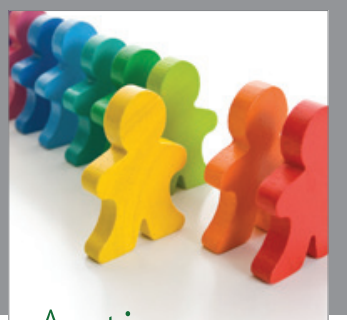

Autism

Research and Treatment
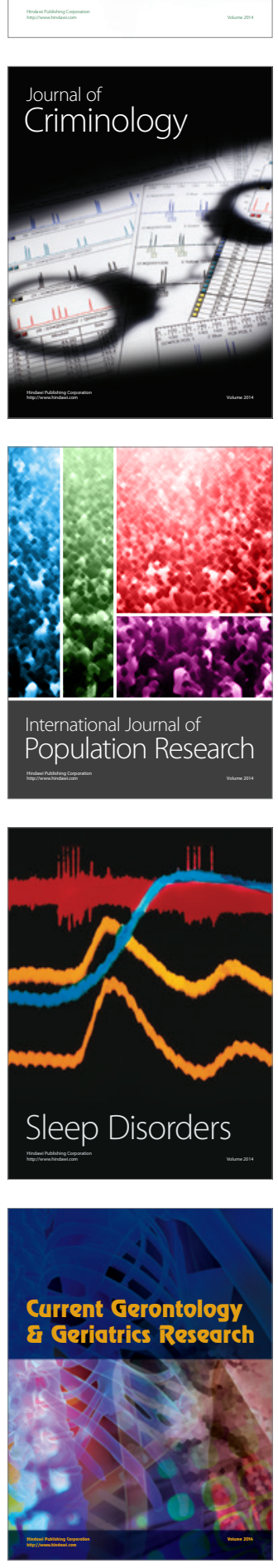
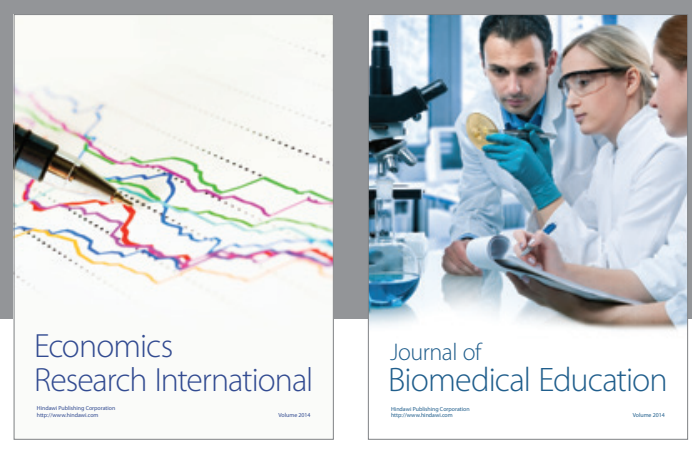

Journal of

Biomedical Education

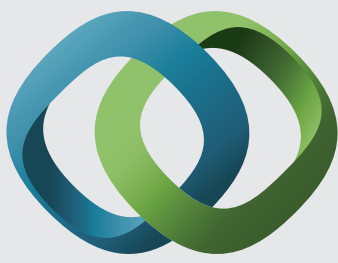

\section{Hindawi}

Submit your manuscripts at

http://www.hindawi.com
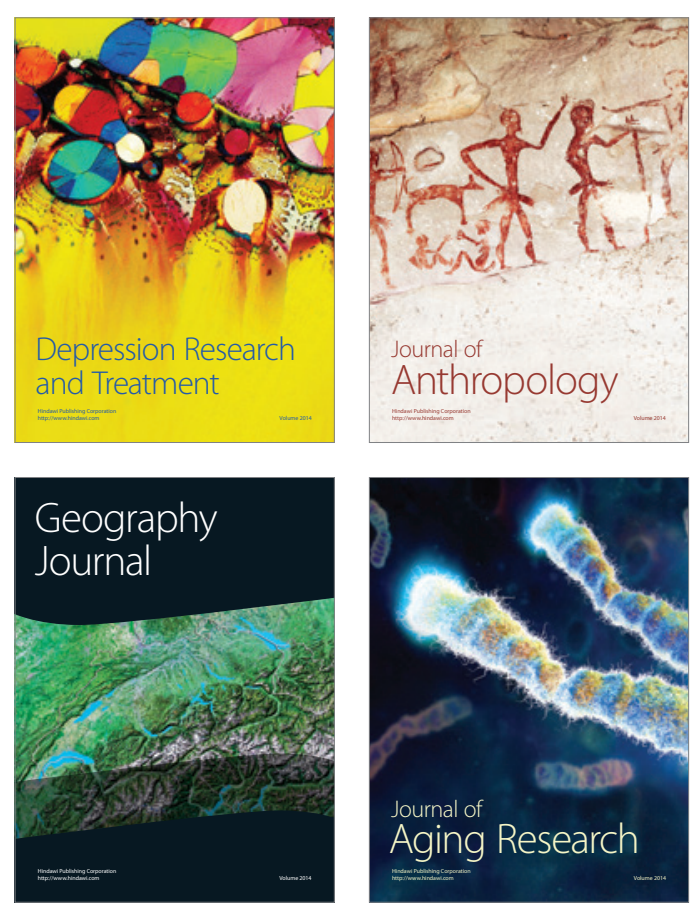

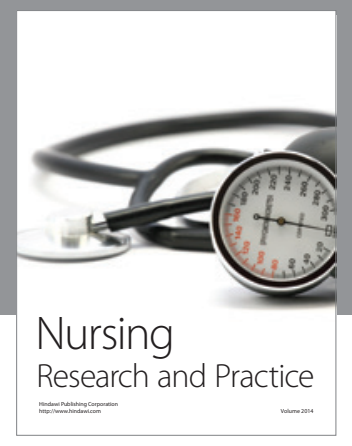

Nursing

Research and Practice

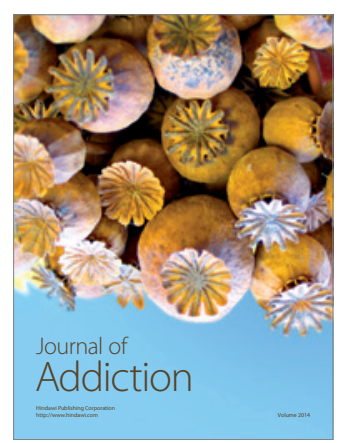

Child Development

Research

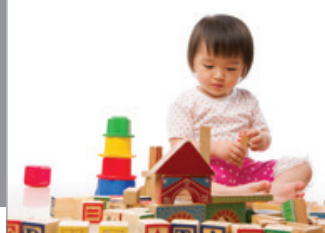

迥
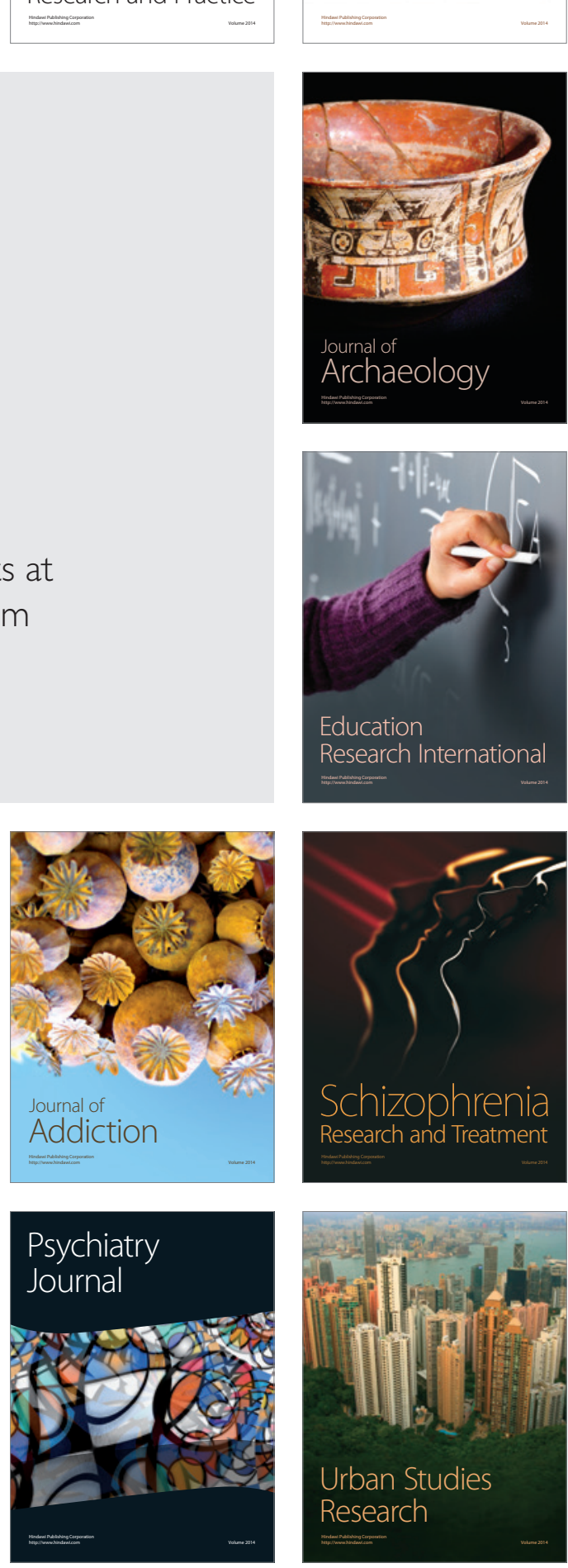